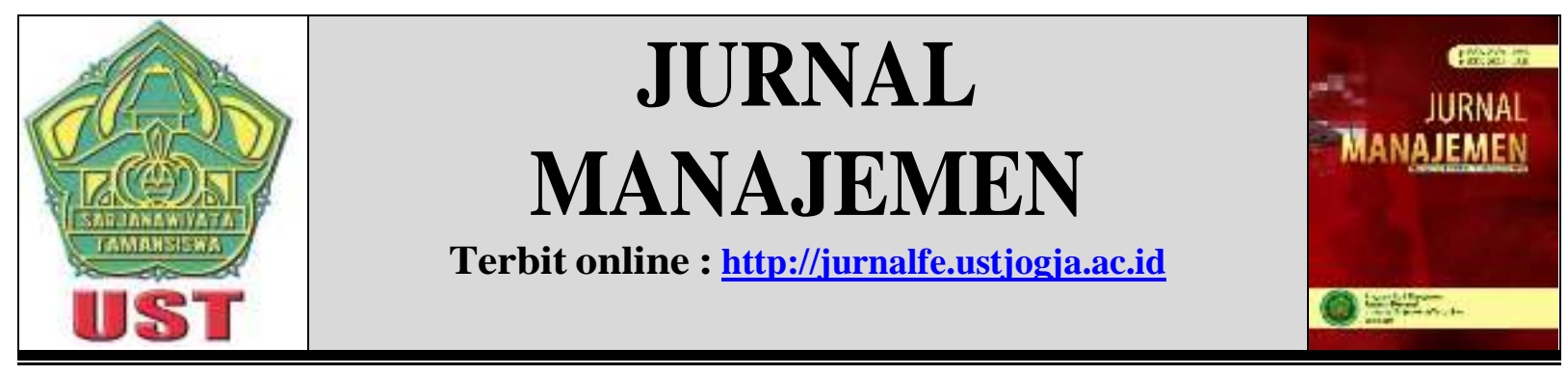

\title{
PENGARUH KUALITAS PELAYANAN, HARGA DAN KUALITAS PRODUK TERHADAP LOYALITAS PELANGGAN DENGAN KEPUASAN KONSUMEN SEBAGAI VARIABEL INTERVENING (Studi Pada Jasa Pelatihan UVI Consultant Yogyakarta)
}

\author{
Suhartono ${ }^{1}$ \\ Dwi Rahayu' ${ }^{2}$
}

1,2 STIE Widya Wiwaha Yogyakarta

E-mail: avicenasuhartono@yahoo.co.id ${ }^{1}$; rahayudwi474@ gmail.com ${ }^{2}$

\begin{tabular}{|c|c|}
\hline Informasi Naskah & Abstrak \\
\hline $\begin{array}{l}\text { Diterima: } \\
\text { 8 Februari } 2021 \\
\text { Revisi: } \\
\text { 13 Februari } 2021 \\
\text { Terbit: } \\
\text { 18 Juni } 2021\end{array}$ & $\begin{array}{l}\text { Services are basically intact and leave no ownership } \\
\text { whatsoever. A large business competition in the service industry } \\
\text { requires that companies work hard to understand the needs and wants of } \\
\text { their customers. How companies can improve their services } \\
\text { professionally, so that consumers are satisfied with what they have } \\
\text { gained that they can create loyalty. The research aims to know whether }\end{array}$ \\
\hline $\begin{array}{ll}\text { Keywords: } & \\
\text { Service quality, } & \text { Product } \\
\text { quality, } & \text { customer } \\
\text { satisfaction, } & \text { costumer } \\
\text { loyalty } & \end{array}$ & $\begin{array}{l}\text { the quality of services, prices, quality of products and consumer } \\
\text { satisfaction affect customer loyalty and whether consumer satisfaction } \\
\text { can be increased between service quality, price, product quality to } \\
\text { customer loyalty in the uvi temple service. The population in this } \\
\text { research is all the customers who have used training services at uvi } \\
\text { consultants. The sample in the study numbered 200, using a factory- } \\
\text { bound approach, a sample withdrawal method based on a given } \\
\text { consideration. The method of data collection used in this study is } \\
\text { questionnaires and USES the likert scale. } \\
\text { The results of the tests indicate that the quality of service, price } \\
\text { and quality have a positive and significant impact on consumer } \\
\text { satisfaction. Service quality, price, product quality and consumer } \\
\text { satisfaction also have a positive and significant impact on customer } \\
\text { loyalty. With a path analysis or analysis of the magnitude of the indirect } \\
\text { influence is greater than the direct influence so the consumer } \\
\text { satisfaction is capable of mitigating between the impact of the quality of } \\
\text { service, the price and the quality of the product on customer loyalty. }\end{array}$ \\
\hline
\end{tabular}

\section{PENDAHULUAN}

Di era saat ini bisnis telah berkembang pesat, khususnya dalam bidang jasa. Banyaknya persaingan bisnis di bidang jasa mengharuskan perusahaan untuk bekerja keras memahami kebutuhan dan keinginan pelanggannya. Bagaimana perusahaan untuk dapat meningkatkan pelayanan secara profesional, sehingga konsumen merasa puas dengan apa yang telah mereka dapatkan. Oleh karena itu perusahaan jasa training atau pelatihan UVI Consultant berusaha terus meningkatkan kualitas pelayanan untuk menjaga kepercayaan dan loyalitas pelanggannya. Loyalitas 
pelanggan mempunyai peranan yang penting dalam sebuah perusahaan, mempertahankan mereka berarti meningkatkan kinerja keuangan dan mempertahankan kelangsungan hidup perusahaan. Ada beberapa hal yang berkaitan dengan loyalitas antara lain kualitas pelayanan, harga dan kualitas produk.

Kualitas pelayanan merupakan hal yang penting bagi perusahaan terutama dalam bidang jasa. Menurut Wyckof, kualitas pelayanan atau jasa merupakan tingkat keunggulan yang diharapkan dan pengendalian atas keunggulan tersebut untuk memenuhi keinginan pelanggan (Fandy Tjiptono, 2014:268).

Harga merupakan komponen yang digunakan perusahaan dalam membentuk strategi pemasaran. Menurut Kotler dan Amstrong, harga adalah sejumlah nilai yang dibebankan atas suatu produk atau jasa yang diberikan oleh konsumen untuk memperoleh keuntungan dari memiliki atau menggunakan produk atau jasa tersebut (Rina Sukmawati, 2017:4)

Kualitas produk juga merupakan hal yang penting terhadap kepuasan dan loyalitas pelanggan. Menurut Kotler dan Amstrong, kualitas produk adalah segala sesuatu yang dapat ditawarkan ke pasar untuk mendapatkan perhatian, dibeli, digunakan atau dikonsumsi yang dapat memuaskan keinginan atau kebutuhan (Yusuf Helmi, 2019:18).

Berdasarkan uraian di atas maka dalam penelitian ini diambil judul "Pengaruh Kualitas Pelayanan, Harga dan Kualitas Produk Terhadap Loyalitas Pelanggan Dengan Kepuasan Konsumen Sebagai Variabel Intervening pada Usaha Jasa Pelatihan di UVI Consultant”.

\section{KAJIAN PUSTAKA DAN HIPOTESIS \\ Kualitas Pelayanan}

Menurut Goeth \& Davis kualitas pelayanan merupakan suatu kondisi dinamis yang berhubungan dengan produk, jasa, manusia, proses dan lingkungan yang mampu memenuhi dan melebihi harapan pelanggan. Sedangkan kualitas pelayanan menurut Gronroos, adalah suatu aktivitas atau serangkaian aktivitas yang bersifat tidak kasat mata yang terjadi sebagai akibat adanya interaksi antara konsumen dengan karyawan atau hal-hal lain yang disediakan oleh perusahaan pemberi pelayanan yang dimaksud untuk memecahkan permasalahan konsumen atau pelanggan (Aris Irnanda, 2016: 3 \& 21).

\section{Harga}

Menurut Kotler dan Amstrong, harga adalah sejumlah nilai yang dibebankan atas suatu produk atau jasa yang diberikan oleh konsumen untuk memperoleh keuntungan dari menggunakan produk atau jasa (Rina Sukmawati, 2017:22). Fandy Tjiptono mendefinisikan harga sebagai satuan moneter atau ukuran lainnya (termasuk barang dan jasa lainnya) yang ditukarkan agar memperoleh hak kepemilikan atau penggunaan suatu barang atau jasa. Sedangkan menurut Basu Swasta, harga adalah jumlah uang (ditambah beberapa produk kalau mungkin) yang dibutuhkan untuk mendapat sejumlah kombinasi dari produk dan pelayanannya (Yineu Nur Layaalin, 2017:27-28).

\section{Kualitas Produk}

Menurut Goetsch dan Davis, kualitas merupakan suatu kondisi dinamis yang berhubungan dengan produk, jasa sumberdaya manusia, proses dan lingkungan yang memenuhi harapan konsumen. Sedangkan menurut Mowen dan Minor, kualitas produk merupakan evaluasi yang dilakukan oleh konsumen atas kebaikan kinerja barang atau jasa (Rina Sukmawati, 2017:15).

\section{Kepuasan Konsumen}

Menurut Schiffman, Kanuk \& Wisenbilt perilaku konsumen merupakan perilaku yang ditunjukan oleh konsumen dalam mencari, membeli, menggunakan, mengevaluasi, dan menghentikan konsumsi produk atau jasa yang mereka harapkan dapat memuaskan kebutuhan mereka (Fandy Tjiptono, 2014:50). 


\section{Pengembangan Hipotesis}

1. Yusuf Helmi Aziz (2019) melakukan penelitian dengan judul "Analisis Pengaruh Kualitas Produk dan Harga Terhadap Keputusan Pembelian Melalui Word of Mouth Sebagai Variabel Intervening" (Studi Pada Pembeli Es Coklat Ndeso di Taman Paseban Kabupaten Bantul). Hasil dari penelitiannya menunjukkan bahwa secara parsial Kualitas Produk dan Harga berpengaruh positif terhadap Keputusan Pembelian. Serta melalui Word of Mouth tidak berpengaruh positif terhadap Keputusan Pembelian.

2. Indah Dwi Kurniasih (2012) melakukan penelitian dengan judul "Pengaruh Harga dan Kualitas Pelayanan Terhadap Loyalitas Pelanggan Melalui Variabel Kepuasan" (Studi Pada Bengkel Ahass 0002-Astra Motor Siliwangi Semarang). Penelitian menyimpulkan bahwa pengaruh langsung harga terhadap loyalitas lebih besar daripada pengaruh tidak langsungnya. Sedangkan pengaruh langsung kualitas pelayanan terhadap loyalitas lebih besar daripada pengaruh tidak langsungnya. Pengaruh total harga terhadap loyalitas lebih kecil daripada pengaruh total kualitas pelayanan terhadap loyalitas.

3. Ani Lestari (2018) melakukan penelitian dengan judul "Pengaruh Kualitas Produk Terhadap Loyalitas Pelanggan Dengan Kepuasan Pelanggan Sebagai Variabel Mediasi” (Survey Pada Pelanggan Citra Kendedes Cake \& Bakery Kota Malang). Berdasarkan analisis jalur menunjukkan bahwa variabel kualitas produk berpengaruh signifikan terhadap kepuasan pelanggan, Variabel kualitas produk berpengaruh signifikan terhadap loyalitas pelanggan, Dan variabel kepuasan pelanggan berpengaruh signifikan terhadap loyalitas pelanggan.

Berdasarkan teori dan hasil beberapa penelitian maka dapat diambil beberapa hipotesis sebagai berikut:

H1: Kualitas Pelayanan berpengaruh positif signifikan terhadap kepuasan konsumen.

H2: Harga berpengaruh positif dan signifikan terhadap kepuasan konsumen

H3: Kualitas Produk berpengaruh positif dan signifikan terhadap kepuasan konsumen

H4: Kualitas Pelayanan berpengaruh positif dan signifikan terhadap Loyalitas Pelanggan

H5: Harga berpengaruh positif dan signifikan terhadap loyalitas pelanggan

H6: Kualitas Produk berpengaruh positif dan signifikan terhadap loyalitas pelanggan

H7: Kepuasan konsumen berpengaruh positif dan signifikan terhadap loyalitas pelanggan

Hs: Kepuasan kosumen mampu memediasi kualitas pelayanan terhadap loyalitas pelanggan

H9: Kepuasan kosumen mampu memediasi harga terhadap loyalitas pelanggan

H10: Kepuasan kosumen mampu memediasi kualitas produk terhadap loyalitas pelanggan

Adapun berdasarkan pengembangan hipotesis tersebut maka dapat digambarkan model penelitian sebagai berikut:

\section{Model Penelitian}

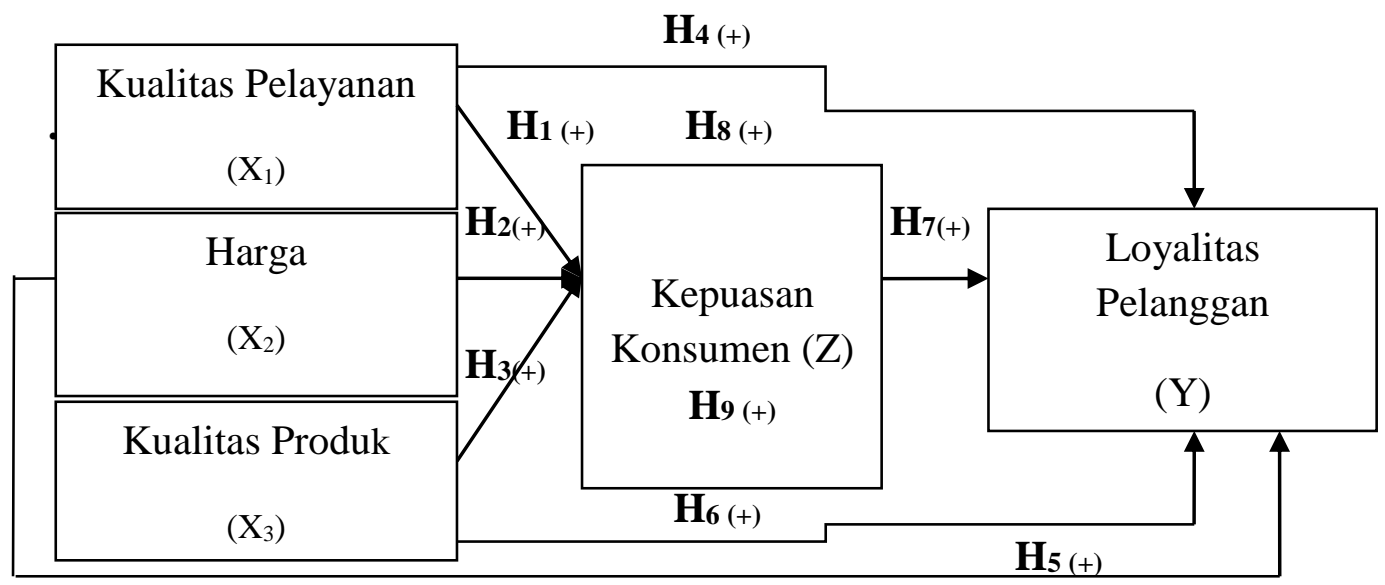

Gambar 1 Model Penelitian 


\section{METODE PENELITIAN}

Penelitian ini merupakan penelitian kuantitatif, teknik pengambilan sampel dilakukan secara random, pengumpulan data menggunakan instrumen penelitian, analisis data bersifat kuantitatif atau statistik dengan tujuan untuk menguji hipotesis yang telah ditetapkan (Sugiono, 2009:14). Penelitian ini akan dilakukan di CV Universal Vision Indonesia dengan populasi dalam penelitian ini yaitu seluruh pelanggan yang menggunakan jasa pelatihan atau training di UVI Consultant. Tekning sampling yang digunakan dalam penelitian ini adalah purposive sampling. Teknik purposive sampling adalah teknik penentuan sampel dengan pertimbangan tertentu (Sugiyono, 2012:68).

\section{Variabel Penelitian}

Menurut Sugiyono (2012:2) variabel penelitian adalah sesuatu yang berbentuk apa saja yang ditetapkan oleh seorang peneliti untuk dipelajari sehingga diperoleh informasi mengenai hal tersebut, kemudian ditarik kesimpulannya. Dalam penelitian ini ada 3 (tiga) macam variabel penelitian yakni: Varibel Bebas (Independent), Variabel Terikat (Dependent), Variabel Intervening (Mediasi). Adapun definisi operasional variabel adalah:

Tabel 1

Definisi Operasional Variabel

\begin{tabular}{|c|c|c|}
\hline Variabel & $\begin{array}{c}\text { Jenis } \\
\text { Variabel }\end{array}$ & Indikator \\
\hline $\begin{array}{l}\text { Kualitas } \\
\text { Pelayanan } \\
\text { (X1) }\end{array}$ & Bebas & $\begin{array}{l}\text { 1. Tangible (bukti fisik) } \\
\text { 2. Reliability (keandalan) } \\
\text { 3. Responsiveness (ketanggapan) } \\
\text { 4. Assurance (jaminan atau kepastian) } \\
\text { 5. Empathy (kepedulian) }\end{array}$ \\
\hline $\begin{array}{l}\text { Harga } \\
(\mathrm{X} 2)\end{array}$ & Bebas & $\begin{array}{l}\text { 1. Keterjangkauan harga } \\
\text { 2. Kesesuaian harga dengan kualitas produk } \\
\text { 3. Daya saing harga } \\
\text { 4. Kesesuaian harga dengan manfaat }\end{array}$ \\
\hline $\begin{array}{l}\text { Kualitas } \\
\text { Produk } \\
\text { (X3) }\end{array}$ & Bebas & $\begin{array}{l}\text { 1. Kinerja (performance) } \\
\text { 2. Daya Tahan } \\
\text { 3. Kesesuaian dengan Spesifikasi } \\
\text { 4. Produk memiliki banyak variasi } \\
\text { 5. Fitur atau keistimewaan }\end{array}$ \\
\hline $\begin{array}{l}\text { Kepuasan } \\
\text { Konsumen } \\
\text { (Z) }\end{array}$ & Mediator & $\begin{array}{l}\text { 1. Kesesuaian harapan } \\
\text { 2. Minat berkunjung kembali } \\
\text { 3. Kesediaan merekomendasikan }\end{array}$ \\
\hline $\begin{array}{l}\text { Loyalitas } \\
\text { Pelanggan } \\
\text { (Y) }\end{array}$ & Terikat & $\begin{array}{l}\text { 1. Melakukan pembelian ulang secara teratur } \\
\text { 2. Membeli antar lini produk atau jasa } \\
\text { 3. Merekomendasikan produk kepada orang lain } \\
\text { 4. Menunjukkan daya tarik produk sejenis dari } \\
\text { pesaing }\end{array}$ \\
\hline
\end{tabular}

\section{Uji Instrumen Penelitian}

Instrumen penelitian berupa kuisioner telah melalui uji validitas dan uji reliabilitas yang hasilnya valid dan reliabel. Instrumen yang valid dan reliable dapat digunakan kembali pada studi empiris yang sama. Instrumen penelitian juga telah terbentuk melalui penyesuaian kajian teori dan studi empiris variabel-variabel loyalitas pelanggan. 


\section{Teknik Analisis Data}

\section{Uji Asumsi Klasik}

Uji asumsi klasik bertujuan untuk mengetahui kondisi data yang dipergunakan dalam penelitian. Uji yang dilakukan adalah uji normalitas, uji multikolinieritas, dan uji heteroskedastisitas. Dari hasil uji ini dapat dinyatakan bahwa data penelitian ini telah lolos dari uji asumsi klasik, yang artinya bahwa data bisa dilanjutkan untuk dianalisis pada tahap berikutnya.

\section{Metode Analisis Jalur (Path Analysis)}

Metode analisis jalur digunakan untuk mengetahui pengaruh hubungan secara tidak langsung. Biasanya digunakan dalam model penelitian yang menggunkaan variabel mediasi atau intervening.

\section{Analisis Regresi Linier Berganda}

Menurut Sugiyono (2012), analisis regresi linier berganda digunakan untuk meramalkan bagaimana keadaan (naik turunnya) variabel dependen (kriterium), bila dua tau lebih variabel independen sebagai faktor prediktor dimanipulasi (dinaik turunkan nilainya). Adapun persamaan yang digunakan sebagai berikut:

$$
\begin{array}{r}
Y_{Z}=a+b_{1} X_{1}+b_{2} X_{2}+b_{3} X_{3}+e \ldots . .(1) \\
Y=a+b_{1} X_{1}+b_{2} X_{2}+b_{3} X_{3}+b_{4} Z+e \ldots(2)
\end{array}
$$

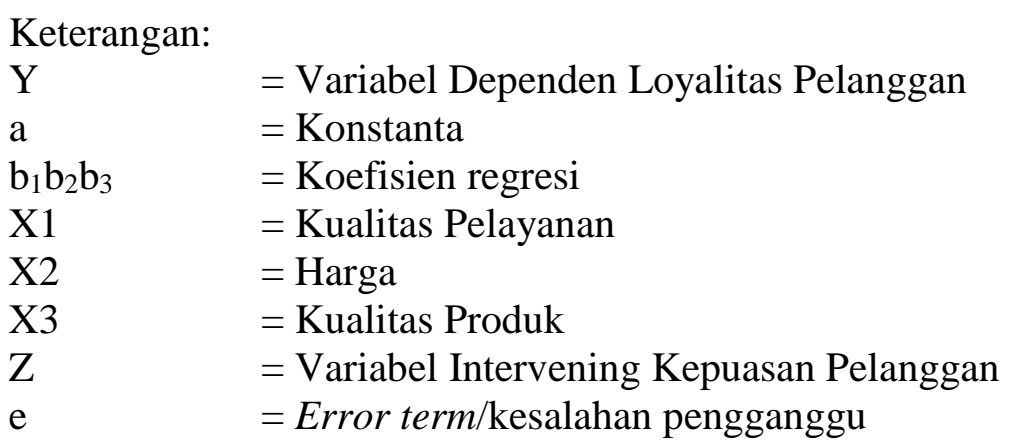

\section{Uji Hipotesis}

\section{Uji F (Uji Simultan)}

Uji F digunakan untuk mengukur pengaruh variabel bebas (independen) terhadap variabel terikat secara bersama-sama atau simultan, Jika $p$-value $<0,05$ maka variabel independen secara simultan berpengaruh signifikan terhadap variabel dependen.

\section{Uji T (Uji Parsial)}

Uji t mengukur pengaruh variabel bebas (independen) terhadap variabel terikat secara parsial atau individu. Jika $p$-value $<0,05$ maka variabel independen secara parsial berpengaruh signifikan terhadap variabel dependen.

\section{Koefisien Determinasi (R Square)}

Menurut Ghozali (2016:95), koefisien determinasi $\left(\boldsymbol{R}^{2}\right)$ pada intinya mengukur seberapa jauh kemampuan sebuah model menerangkan variasi variabel dependen. Nilai koefisien determinasi adalah antara nol dan satu. Nilai $\left(\boldsymbol{R}^{2}\right)$ yang kecil berarti kemmpuan variabel-variabel bebas dalam menjelaskan variabel terikat sangat terbatas.

\section{HASIL DAN PEMBAHASAN}

\section{Analisis Regresi I}

$Y_{Z}=\mathbf{a}+\mathbf{b}_{1} X_{1}+b_{2} X_{2}+b_{3} X_{3}+e_{1}$ 


\section{Pengaruh Kualitas Pelayanan, Harga dan Kualitas Produk Secara Simultan Terhadap Kepuasan Konsumen}

Dari hasil perhitungan, diperoleh angka F-hitung sebesar 77,232 > F-tabel sebesar 2,65 sehingga Ho ditolak dan Ha diterima. Dengan demikian model regresi tersebut sudah layak dan benar. Kesimpulanya adalah kualitas pelayanan, harga dan kualitas produk secara simultan mempengaruhi kepuasan konsumen. Besar pengaruhnya adalah 54,2\% dan signifikan dengan signifikansi $0,000<\alpha$ $=0,05$. Besar pengaruh variabel lain di luar model regresi tersebut dihitung dengan rumus: $\left(1-r^{2}\right)$ atau $(1-0,542)=0,458$ atau sebesar $45,8 \%$.

\section{Pengaruh Kualitas Pelayanan, Harga dan Kualitas Produk Secara Parsial Terhadap Kepuasan Konsumen}

Besarnya angka t-tabel dengan ketentuan $\alpha=0,05$ yaitu $(\alpha / 2 ; n-k-1)$ atau $(0,05 / 2 ; 200-3-1)=0,025$ ; 196. Diperoleh angka t-tabel sebesar 1,97214.

a. Pengaruh Kualitas Pelayanan terhadap Kepuasan Konsumen

Berdasarkan hasil perhitungan, diperoleh angka t-hitung sebesar 5,877 > t-tabel yaitu 1,97214. Sehingga Ho ditolak dan Ha diterima. Artinya ada pengaruh antara kualitas pelayanan terhadap kepuasan konsumen. Besarnya pengaruh kualitas pelayanan terhadap kepuasan konsumen = 0,245 atau $24,5 \%$ dianggap signifikan dengan angka signifikansi $0,000<\alpha 0,05$.

b. Pengaruh Harga terhadap Kepuasan Konsumen

Berdasarkan hasil perhitungan, diperoleh angka t-hitung sebesar 6,469>t-tabel yaitu 1,97214. Sehingga Ho ditolak dan Ha diterima. Artinya ada pengaruh antara harga terhadap kepuasan konsumen. Besarnya pengaruh harga terhadap kepuasan konsumen $=0,399$ atau 39,9\% dianggap signifikan dengan angka signifikansi $0,000<\alpha 0,05$.

c. Pengaruh Kualitas Produk terhadap Kepuasan Konsumen

Berdasarkan hasil perhitungan, diperoleh angka t-hitung sebesar 6,932 > t-tabel yaitu 1,97214. Sehingga Ho ditolak dan Ha diterima. Artinya ada pengaruh antara kualitas produk terhadap kepuasan konsumen. Besarnya pengaruh kualitas produk terhadap kepuasan konsumen $=0,367$ atau $36,7 \%$ dianggap signifikan dengan angka signifikansi $0,000<\alpha 0,05$.

\section{Persamaan II \\ $\mathbf{Y}=\mathbf{a}+\mathbf{b}_{1} \mathbf{X}_{1}+\mathbf{b}_{2} \mathbf{X}_{2}+\mathbf{b}_{3} \mathbf{X}_{3}+\mathbf{b}_{4} Z+\mathbf{e}_{2}$}

Pengaruh Kualitas Pelayanan, Harga, Kualitas Produk dan Kepuasan Pelanggan secara Simultan terhadap Loyalitas Pelanggan

Dari hasil perhitungan, diperoleh angka F-hitung sebesar 236,199 > F-tabel sebesar 2,42 sehingga Ho ditolak dan Ha diterima. Dengan demikian model regresi tersebut sudah layak dan benar. Kesimpulanya adalah kualitas pelayanan, harga, kualitas produk dan kepuasan konsumen secara simultan mempengaruhi loyalitas pelanggan. Besar pengaruhnya adalah 82,9\% dan signifikan dengan signifikansi $0,000<\alpha=0,05$. Besar pengaruh variabel lain di luar model regresi tersebut dihitung dengan rumus: $\left(1-r^{2}\right)$ atau $(1-0,829)=0,171$ atau sebesar $17,1 \%$.

\section{Pengaruh Kualitas Pelayanan, Harga, Kualitas Produk dan Kepuasan Secara Parsial Terhadap Loyalitas Pelanggan}

Besarnya angka t-tabel dengan ketentuan $\alpha=0,05$ yaitu $(\alpha / 2 ; n-k-1)$ atau $(0,05 / 2 ; 200-4-1)=0,025$ ; 195. Maka diperoleh angka t-tabel sebesar 1,97220.

a. Pengaruh Kualitas Pelayanan terhadap Loyalitas Pelanggan

Berdasarkan hasil perhitungan, diperoleh angka t-hitung sebesar 2,811 > t-tabel yaitu 1,97220. Sehingga Ho ditolak dan Ha diterima. Artinya ada pengaruh antara kualitas pelayanan terhadap loyalitas pelanggan. Besarnya pengaruh kualitas pelayanan terhadap loyalitas pelanggan $=0,076$ atau 7,6\% dianggap signifikan dengan angka signifikansi $0,005<\alpha 0,05$. 
b. Pengaruh Harga terhadap Loyalitas Pelanggan

Berdasarkan hasil perhitungan, diperoleh angka t-hitung sebesar 3,729 > t-tabel yaitu 1,97220. Sehingga Ho ditolak dan Ha diterima. Artinya ada pengaruh antara harga terhadap loyalitas pelanggan. Besarnya pengaruh harga terhadap loyalitas pelanggan $=0,144$ atau $14,4 \%$ dianggap signifikan dengan angka signifikansi $0,000<\alpha 0,05$.

c. Pengaruh Kualitas Produk terhadap Loyalitas Pelanggan

Berdasarkan hasil perhitungan, diperoleh angka t-hitung sebesar 3,472 > t-tabel yaitu 1,97220. Sehingga Ho ditolak dan Ha diterima. Artinya ada pengaruh antara kualitas produk terhadap loyalitas pelanggan. Besarnya pengaruh kualitas produk terhadap loyalitas pelanggan $=0,130$ atau 13\% dianggap signifikan dengan angka signifikansi $0,001<\alpha 0,05$.

d. Pengaruh Kepuasan terhadap Loyalitas Pelanggan

Berdasarkan hasil perhitungan, diperoleh angka t-hitung sebesar 16,067 > t-tabel yaitu 1,97220. Sehingga Ho ditolak dan Ha diterima. Artinya ada pengaruh antara kepuasan terhadap loyalitas pelanggan. Besarnya pengaruh kepuasan terhadap loyalitas pelanggan $=0,689$ atau $68,9 \%$ dianggap signifikan dengan angka signifikansi $0,000<\alpha 0,05$.

\section{Pengaruh Langsung, Tidak Langsung dan Pengaruh Total}

1. Direct Effect (Pengaruh Langsung)

$\mathbf{X 1} \rightarrow \mathbf{Z}=\mathbf{0 , 3 0 8}$ Hal ini menunjukkan bahwa variabel kualitas pelayanan berpengaruh secara signifikan terhadap kepuasan konsumen, ditunjukkan dengan nilai coefficient beta sebesar 0,308 dan tingkat signifikansi sebesar 0,000.

$\mathbf{X 2} \rightarrow \mathbf{Z}=\mathbf{0 , 3 7 4}$ Hal ini menunjukkan bahwa variabel harga berpengaruh secara signifikan terhadap kepuasan konsumen, ditunjukkan dengan nilai coefficient beta sebesar 0,374 dan tingkat signifikansi sebesar 0,000 .

$\mathbf{X 3} \rightarrow \mathbf{Z}=\mathbf{0 , 3 2 9}$ Hal ini menunjukkan bahwa variabel kualitas produk berpengaruh secara signifikan terhadap kepuasan konsumen, ditunjukkan dengan nilai coefficient beta sebesar 0,329 dan tingkat signifikansi sebesar 0,000.

$\mathbf{X 1} \rightarrow \mathbf{Y}=\mathbf{0 , 0 9 8}$ Hal ini menunjukkan bahwa variabel kualitas pelayanan berpengaruh secara signifikan terhadap loyalitas pelanggan, ditunjukkan dengan nilai coefficient beta sebesar 0,098 dan tingkat signifikansi sebesar 0,005.

$\mathbf{X} \mathbf{2} \rightarrow \mathbf{Y}=\mathbf{0 , 1 3 7}$ Hal ini menunjukkan bahwa variabel harga berpengaruh secara signifikan terhadap loyalitas pelanggan, ditunjukkan dengan nilai coefficient beta sebesar 0,137 dan tingkat signifikansi sebesar 0,000 .

$\mathbf{X 3} \rightarrow \mathbf{Y}=\mathbf{0 , 1 1 9}$ Hal ini menunjukkan bahwa variabel kualitas produk berpengaruh secara signifikan terhadap loyalitas pelanggan, ditunjukkan dengan nilai coefficient beta sebesar 0,119 dan tingkat signifikansi sebesar 0,001 .

$\mathbf{Z} \rightarrow \mathbf{Y}=\mathbf{0 , 7 0 3}$ Hal ini menunjukkan bahwa variabel kualitas produk berpengaruh secara signifikan terhadap loyalitas pelanggan, ditunjukkan dengan nilai coefficient beta sebesar 0,703 dan tingkat signifikansi sebesar 0,000 .

\section{Indirect Effect (Pengaruh Tidak Langsung)}

$\mathrm{X} 1 \rightarrow \mathrm{Z} \rightarrow \mathrm{Y}=0,308 \times 0,703=0,216524$

Pengaruh secara tidak langsung antara kualitas pelayanan terhadap loyalitas melalui kepuasan konsumen adalah sebesar 0,216524 .

$\mathrm{X} 2 \rightarrow \mathrm{Z} \rightarrow \mathrm{Y}=0,374 \times 0,703=0,262922$

Pengaruh secara tidak langsung antara harga terhadap loyalitas melalui kepuasan konsumen adalah sebesar 0,262922

$\mathrm{X} 3 \rightarrow \mathrm{Z} \rightarrow \mathrm{Y}=0,329 \times 0,703=0,231287$

Pengaruh secara tidak langsung antara harga terhadap loyalitas melalui kepuasan konsumen adalah sebesar 0,231287 


\section{Total Effect (Pengaruh Total)}

Direct Effect + Indirect Effect $=0,098+0,216524=0,314524$

Pengaruh total antara kualitas pelayanan terhadap loyalitas melalui kepuasan konsumen adalah sebesar $=0,314524$

Direct Effect + Indirect Effect $=0,119+0,231287=0,350287$

Pengaruh total antara harga terhadap loyalitas melalui kepuasan konsumen adalah sebesar $=$ 0,350287

Direct Effect + Indirect Effect $=0,119+0,231287=0,350287$

Pengaruh total antara kualitas produk terhadap loyalitas melalui kepuasan konsumen adalah sebesar 0,350287

\section{Pengaruh Kualitas Pelayanan $\left(\mathbf{X}_{1}\right)$ terhadap Loyalitas Pelanggan (Y)}

Diketahui pengaruh langsung antara kualitas pelayanan $\left(\mathrm{X}_{1}\right)$ terhadap loyalitas pelanggan $(\mathrm{Y})$ sebesar 0,098 dan pengaruh tidak langsung antara kualitas pelayanan $\left(\mathrm{X}_{1}\right)$ terhadap loyalitas pelanggan (Y) melalui kepuasan konsumen (Z) sebesar 0,216524. Hal ini berarti nilai pengaruh tidak langsung lebih besar daripada pengaruh langsung, hasil menunjukkan bahwa secara tidak langsung kualitas pelayanan $\left(\mathrm{X}_{1}\right)$ melalui kepuasan konsumen $(\mathrm{Z})$ mempunyai pengaruh signifikan terhadap loyalitas pelanggan $(\mathrm{Y})$.

\section{Pengaruh Harga $\left(\mathbf{X}_{2}\right)$ terhadap Loyalitas Pelanggan (Y)}

Diketahui pengaruh langsung antara harga $\left(\mathrm{X}_{2}\right)$ terhadap loyalitas pelanggan $(\mathrm{Y})$ sebesar 0,137 dan pengaruh tidak langsung antara harga $\left(\mathrm{X}_{2}\right)$ terhadap loyalitas pelanggan $(\mathrm{Y})$ melalui kepuasan konsumen (Z) sebesar 0,262922. Hal ini berarti nilai pengaruh tidak langsung lebih besar daripada pengaruh langsung, hasil menunjukkan bahwa secara tidak langsung harga $\left(\mathrm{X}_{2}\right)$ melalui kepuasan konsumen (Z) mempunyai pengaruh signifikan terhadap loyalitas pelanggan (Y).

\section{Pengaruh Kualitas Produk ( $\left.\mathbf{X}_{3}\right)$ terhadap Loyalitas Pelanggan (Y)}

Diketahui pengaruh langsung antara kualitas produk $\left(\mathrm{X}_{3}\right)$ terhadap loyalitas pelanggan $(\mathrm{Y})$ sebesar 0,119 dan pengaruh tidak langsung antara kualitas produk $\left(\mathrm{X}_{3}\right)$ terhadap loyalitas pelanggan $(\mathrm{Y})$ melalui kepuasan konsumen $(\mathrm{Z})$ sebesar 0,231287 . Hal ini berarti nilai pengaruh tidak langsung lebih besar daripada pengaruh langsung, hasil menunjukkan bahwa secara tidak langsung kualitas produk $\left(\mathrm{X}_{3}\right)$ melalui kepuasan konsumen $(\mathrm{Z})$ mempunyai pengaruh signifikan terhadap loyalitas pelanggan $(\mathrm{Y})$.

\section{PEMBAHASAN}

\section{Pengaruh Kualitas Pelayanan Terhadap Kepuasan Konsumen}

Berdasarkan hasil pengujian dapat dilihat bahwa nilai signifikansi variabel Kualitas Pelayanan $\left(\mathrm{X}_{1}\right)$ sebesar $0,000<0,05$ dan nilai t-hitung $(5,877)>$ dari t-tabel $(1,97214)$. Nilai koefisien dari variabel kualitas pelayanan bernilai positif yaitu 0,245 . Jadi hipotesis yang telah dirumuskan sesuai dengan hasil penelitian sehingga $\mathrm{H}_{1}$ dapat diterima atau dengan kata lain secara parsial kualitas pelayanan berpengaruh positif dan signifikan terhadap kepuasan konsumen pada Jasa Pelatihan UVI Consultant Yogyakarta.

\section{Pengaruh Harga Terhadap Kepuasan Konsumen}

Berdasarkan hasil pengujian dapat dilihat bahwa nilai signifikansi variabel Harga $\left(\mathrm{X}_{2}\right)$ sebesar $0,000<0,05$ dan nilai t-hitung $(6,469)>$ dari t-tabel $(1,97214)$. Nilai koefisien dari variabel harga bernilai positif yaitu 0,399 . Jadi hipotesis yang telah dirumuskan sesuai dengan hasil penelitian sehingga $\mathrm{H}_{2}$ dapat diterima atau dengan kata lain secara parsial harga berpengaruh positif dan signifikan terhadap kepuasan konsumen pada Jasa Pelatihan UVI Consultant Yogyakarta. 


\section{Pengaruh Kualitas Produk Terhadap Kepuasan Konsumen}

Berdasarkan hasil pengujian dapat dilihat bahwa nilai signifikansi variabel Kualitas Produk $\left(\mathrm{X}_{3}\right)$ sebesar $0,000<0,05$ dan nilai t-hitung $(6,932)>$ dari t-tabel $(1,97214)$. Nilai koefisien dari variabel kualitas produk bernilai positif yaitu 0,367 . Jadi hipotesis yang telah dirumuskan sesuai dengan hasil penelitian sehingga $\mathrm{H}_{3}$ dapat diterima atau dengan kata lain secara parsial kualitas produk berpengaruh positif dan signifikan terhadap kepuasan konsumen pada Jasa Pelatihan UVI Consultant Yogyakarta.

\section{Pengaruh Kualitas Pelayanan Terhadap Loyalitas Pelanggan}

Berdasarkan hasil pengujian dapat dilihat bahwa nilai signifikansi variabel Kualitas Pelayanan $\left(\mathrm{X}_{1}\right)$ sebesar $0,005<0,05$ dan nilai t-hitung $(2,811)>$ dari t-tabel $(1,97220)$. Nilai koefisien dari variabel kualitas pelayanan bernilai positif yaitu 0,076 . Jadi hipotesis yang telah dirumuskan sesuai dengan hasil penelitian sehingga $\mathrm{H}_{4}$ dapat diterima atau dengan kata lain secara parsial kualitas pelayanan berpengaruh positif dan signifikan terhadap loyalitas pelanggan pada Jasa Pelatihan UVI Consultant Yogyakarta.

\section{Pengaruh Harga Terhadap Loyalitas Pelanggan}

Berdasarkan hasil pengujian dapat dilihat bahwa nilai signifikansi variabel Harga $\left(\mathrm{X}_{2}\right)$ sebesar $0,000<0,05$ dan nilai t-hitung $(3,729)>$ dari t-tabel $(1,97220)$. Nilai koefisien dari variabel harga bernilai positif yaitu 0,144 . Jadi hipotesis yang telah dirumuskan sesuai dengan hasil penelitian sehingga $\mathrm{H}_{5}$ dapat diterima atau dengan kata lain secara parsial harga berpengaruh positif dan signifikan terhadap loyalitas pelanggan pada Jasa Pelatihan UVI Consultant Yogyakarta.

\section{Pengaruh Kualitas Produk Terhadap Loyalitas Pelanggan}

Berdasarkan hasil pengujian dapat dilihat bahwa nilai signifikansi variabel Kualitas Produk $\left(\mathrm{X}_{3}\right)$ sebesar $0,001<0,05$ dan nilai t-hitung $(3,472)>$ dari t-tabel $(1,97220)$. Nilai koefisien dari variabel kualitas produk bernilai positif yaitu 0,130 . Jadi hipotesis yang telah dirumuskan sesuai dengan hasil penelitian sehingga $\mathrm{H}_{6}$ dapat diterima atau dengan kata lain secara parsial kualitas produk berpengaruh positif dan signifikan terhadap loyalitas pelanggan pada Jasa Pelatihan UVI Consultant Yogyakarta.

\section{Pengaruh Kepuasan Konsumen Terhadap Loyalitas Pelanggan}

Berdasarkan hasil pengujian dapat dilihat bahwa nilai signifikansi variabel Kepuasan (Z) sebesar $0,000<0,05$ dan nilai t-hitung $(16,067)>$ dari t-tabel $(1,97220)$. Nilai koefisien dari variabel kepuasan konsumen bernilai positif yaitu 0,689. Jadi hipotesis yang telah dirumuskan sesuai dengan hasil penelitian sehingga $\mathrm{H}_{7}$ dapat diterima atau dengan kata lain secara parsial kepuasan konsumen berpengaruh positif dan signifikan terhadap loyalitas pelanggan pada Jasa Pelatihan UVI Consultant Yogyakarta.

\section{Kepuasan Konsumen Memediasi Pengaruh Kualitas Pelayanan Terhadap Loyalitas Konsumen}

Berdasarkan hasil pengujian dari analisis jalur, pengaruh langsung antara kualitas pelayanan (X1) terhadap loyalitas pelanggan (Y) sebesar 0,098 dan nilai pengaruh tidak langsung antara kualitas pelayanan (X1) terhadap loyalitas pelanggan (Y) melalui kepuasan konsumen (Z) sebesar 0,216524. Nilai pengaruh tidak langsung lebih besar daripada pengaruh langsung, hasil menunjukkan bahwa secara tidak langsung kualitas pelayanan $\left(\mathrm{X}_{1}\right)$ melalui kepuasan konsumen $(\mathrm{Z})$ mempunyai pengaruh signifikan terhadap loyalitas pelanggan (Y). Sedangkan uji signifikansi dengan sobel test diperoleh nilai $\mathrm{z}(5,471991)>\mathrm{z}$ mutlak $(1,96)$ yang berarti bahwa kepuasan konsumen mampu memediasi pengaruh kualitas pelayanan terhadap loyalitas pelanggan. 


\section{Kepuasan Konsumen Memediasi Pengaruh Harga Terhadap Loyalitas Konsumen}

Berdasarkan hasil pengujian dari analisis jalur, pengaruh langsung antara harga $\left(\mathrm{X}_{2}\right)$ terhadap loyalitas pelanggan $(\mathrm{Y})$ sebesar 0,137 dan pengaruh tidak langsung antara harga $\left(\mathrm{X}_{2}\right)$ terhadap loyalitas pelanggan (Y) melalui kepuasan konsumen (Z) sebesar 0,262922. Hal ini berarti nilai pengaruh tidak langsung lebih besar daripada pengaruh langsung, hasil menunjukkan bahwa secara tidak langsung harga $\left(X_{2}\right)$ melalui kepuasan konsumen $(Z)$ mempunyai pengaruh signifikan terhadap loyalitas pelanggan (Y). Uji signifikansi dengan sobel test diperoleh nilai z $(6,310970)>$ dari 1,96 yang berarti bahwa kepuasan konsumen mampu memediasi pengaruh harga terhadap loyalitas pelanggan.

\section{Kepuasan Konsumen Memediasi Pengaruh Kualitas Produk Terhadap Loyalitas Konsumen}

Berdasarkan hasil pengujian dari analisis jalur, pengaruh langsung antara kualitas produk $\left(\mathrm{X}_{3}\right)$ terhadap loyalitas pelanggan (Y) sebesar 0,119 dan pengaruh tidak langsung antara kualitas produk $\left(\mathrm{X}_{3}\right)$ terhadap loyalitas pelanggan $(\mathrm{Y})$ melalui kepuasan konsumen $(\mathrm{Z})$ sebesar 0,231287 . Hal ini berarti nilai pengaruh tidak langsung lebih besar daripada pengaruh langsung, hasil menunjukkan bahwa secara tidak langsung kualitas produk $\left(\mathrm{X}_{3}\right)$ melalui kepuasan konsumen $(\mathrm{Z})$ mempunyai pengaruh signifikan terhadap loyalitas pelanggan (Y). Uji signifikansi dengan sobel test diperoleh nilai z $(5,964320)>$ dari 1,96 yang berarti bahwa kepuasan konsumen mampu memediasi pengaruh kualitas produk terhadap loyalitas pelanggan.

\section{PENUTUP}

Berdasarkan hasil analisis dan pembahasan yang telah diuraikan sebelumnya maka peneliti dapat menarik simpulan sebagai berikut:

1. Kualitas pelayanan, Harga, dan Kualitas Produk baik secara parsial maupun bersama-sama berpengaruh terhadap Kepuasan Pelanggan.

2. Kualitas pelayanan, Harga, dan Kualitas Produk baik secara parsial maupun bersama-sama berpengaruh terhadap Loyalitas Pelanggan.

3. Kepuasan Pelanggan mampu memediasi pengaruh Kualitas pelayanan, Harga, dan Kualitas Produk terhadap Loyalitas Pelanggan.

Berdasarkan simpulan di atas, dapat disampaikan saran sebagai berikut:

1. Kualitas Pelayanan harus terus dijaga dan ditingkatkan, begitu juga kualitas Produk, sedangkan kebijakan Harga harus senantiasa equivalen dengan pelayanan dan kualitas produk agar pelanggan tetap puas.

2. Kualitas Pelayanan harus terus dijaga dan ditingkatkan, begitu juga kualitas Produk, sedangkan kebijakan Harga harus senantiasa equivalen dengan pelayanan dan kualitas produk agar pelanggan tetap loyal.

3. Kepuasan Pelanggan mampu memediasi pengaruh Kualitas pelayanan, Harga, dan Kualitas Produk terhadap Loyalitas Pelanggan bahkan pengaruh tidak langsung lebih tinggi sehingga perusahaan harus menjaga agar pelanggan selalu puas sehingga loyal terhadap perusahaan.

4. Pengaruh variabel independen terhadap variabel independen baik langsung maupun tidak langsung belum mencapai $100 \%$ yang berarti masih memungkinkan untuk memasukkan variabel lain dalam penelitian berikutnya.

\section{DAFTAR PUSTAKA}

Ahmad Farid Wahyudi, Rois Arifin, M. Hufron. (2018). "Pengaruh Kualitas Pelayanan, Harga dan Kualitas Produk Terhadap Loyalitas Konsumen Melalui Kepuasan Sebagai Variabel Intervening Pada Konsumen Resto Ayam Nelongso Sawojajar.” Jurnal Riset Manajemen Vol. 7 No. 7, Malang: Universitas Negeri Islam Malang. 
Alida Palilati. (2007). "Pengaruh Nilai Pelanggan, Kepuasan Terhadap Loyalitas Nasabah Tabungan Perbankan di Sulawesi Selatan.” Jurnal Ekonomi Manajemen, Sulawesi: Universitas Haluoleo Kendari.

Ani Lestari dan Edi Yulianto. (2018). "Pengaruh Loyalitas Produk Terhadap Loyalitas Pelanggan Dengan Kepuasan Pelanggan Sebagai Variabel Mediasi Pada Pelanggan Citra Kendedes Cake \& Bakery." Jurnal Administrasi Bisnis Vol. 54 No.1, Malang: Universitas Brawijaya Malang

Ari Susanto Wibowo. (2013). "Pengaruh Harga, Kualitas Pelayanan Dan Nilai Pelanggan Terhadap Kepuasan Konsumen Pada Rumah Makan di Kota Purwokerto." Skripsi (tidak dipublikasi), Semarang: Universitas Negeri Semarang.

Aris Irnandha. (2016). "Pengaruh Kualitas Layanan Terhadap Loyalitas Pelanggan Yang Dimediasi Oleh Kepuasan Pelanggan Jasa Pengiriman Jalur Darat JNE Cabang Hijrah Sagan Yogyakarta.” Skripsi (tidak dipublikasi), Yogyakarta: Universitas Negeri Yogyakarta.

Armeliani. (2018). "Pengaruh Kulitas Produk, Harga dan Lokasi Terhadap Keputusan Konsumen Dalam Pembelian Dange Di Desa Benteng Kecamatan Mandale Kabupaten Pangep." Skripsi (tidak dipublikasi), Makassar: Univeritas Negeri Makassar.

Cindy Phasalita Widayatma dan Sri Puji Lestari. (2018). "Pengaruh Kualitas Produk Terhadap Loyalitas Konsumen Dengan Kepuasan Konsumen Sebagai Variabel Intervening Pada Rifa Kuliner Kendal.” Jurnal Ilmiah Vol.7 No. 3, Semarang: UNTAG Semarang.

Dina Amanda. (2017). "Pengujian Kepuasan Sebagai Variabel Intervening Antara Pengaruh Kepercayaan dan Atribut Produk Tabungan Batara IB Terhadap Loyalitas Nasabah PT. Bank Tabungan Negara Syariah Palembang.” Skripsi (tidak dipublikasi), Palembang: UIN Raden Fatah Palembang.

Fandy Tjiptono. (2014). Pemasaran Jasa: Prinsip, Penerapan dan Penelitian, Yogyakarta: Andi Offset.

Fathur Khasanati Amanah. (2019). "Pengaruh Reliability, Responsivienes, Assurance, Empathy, Tangibles Terhadap Loyalitas Pelanggan Dengan Kepuasan Konsumen Sebagai Variabel Intervening Pada Bagai Maskapai Lion di Bandar Udara Internasional Adisucipto Yogyakarta.” Skripsi (tidak dipublikasi), Yogyakarta: STIE Widya Wiwaha.

Ghozali, Imam, (2016) Aplikasi Analisis Multivariete Dengan Program IBM SPSS 23, ed 8, Semarang: Badan Penerbit Universitas Diponegoro.

Ika Mariana Zulaika. (2015) "Pengaruh Kualitas Layanan, Store Image, Kualitas Produk, Lingkungan Belanja dan Harapan Konsumen Terhadap Kepuasan Konsumen Pada Swalayan As Gross Ar-Royan Solo.” Skripsi (tidak dipublikasi), Yogyakarta: Universitas Islam Negeri Sunan Kalijaga.

Indah Dwi Kurniasi. (2012). "Pengaruh Harga dan Kualitas Pelayanan Terhadap Loyalitas Pelanggan Melalui Variabel Kepuasan Pada Bengkel Ahass 0002-Astra Motor Siliwangi Semarang.” Jurnal Administrasi Bisnis Vol. 1 No. 1, Semarang: Universitas Diponegoro.

Katon Wisnu Bhagaskoro. (2017). "Analisis Pengaruh Kualitas Pelayanan dan Harga Terhadap Loyalitas Pelanggan Pada Terrace Cafe Yogyakarta." Skripsi (tidak dipublikasi), Yogyakarta: Universitas Sanata Dharma.

Muidatul Azizah. (2018). "Pengaruh Kepercayaan Terhadap Loyalitas Dengan Kepuasan Pelanggan Sebagai Variabel Intervening Pada Service Three Media Computer Yogyakarta.” Skripsi (tidak dipublikasi), Yogyakarta: STIE Widya Wiwaha.

Rachmad Hidayat. (2009). "Model Terintegrasi Pengaruh Kualitas Layanan, Kualitas Produk Dan Nilai Nasabah Terhadap Kepuasan dan Loyalitas Nasabah Bank." Prosiding Seminar Nasional Mananjemen, Surabaya: Universitas Turonojoyo Madura.

Rina Sukmawati. (2017). "Pengaruh Kualitas Produk, Harga dan Pelayanan Terhadap Kepuasan Konsumen Garden Cafe Koperasi Mahasiswa Universitas Negeri Yogyakarta.” Skripsi (tidak dipublikasi), Yogyakarta: Universitas Negeri Yogyakarta. 
Shena Adaby Amin dan Ngatno. (2016). "Pengaruh Kualitas Pelayanan, Harga dan Kepuasan Terhadap Loyalitas Pengguna Jasa Transportasi Pada PO. Bejeu Jepara.” Jurnal Ilmu Administrasi Bisnis Vol. 5, Semarang: Universitas Diponegoro.

Siti Nurma Rosmitha. (2017). "Pengaruh Harga Promosi dan Kualitas Produk Terhadap Keputusan Pembelian Kartu Paket Internet Pada Mahasiswa Fakultas Ekonomi dan Bisnis Islam UIN Raden Intan Lampung.” Skripsi (tidak dipublikasi), Lampung: UIN Raden Intan Lampung.

Sudarman Sahputra Simanullang. (2018). "Analisis Pengaruh Kualitas Pelayanan Terhadap Loyalitas Konsumen Jasa Transportasi Online Dengan Kepuasan Konsumen Sebagai Variabel Moderating." Skripsi (tidak dipublikasi), Sumatera Utara: Universitas Negeri Islam Sumatera Utara.

Sugiyono. (2009). Metode Penelitian Pendidikan, Pendekatan Kuantitatif, Kualitatif dan R\&D, Bandung: Alfabeta

http://taliabupomai.blogspot.com/2010/10/penelitian-kuantitatif-dan-kualitatif.html).

Sugiyono. (2012). Statistika Untuk Penelitian, Bandung: Alfabeta.

Yeni Mahrini. (2013). "Pengaruh Harga, Kualitas Produk dan Kualitas Pelayanan Terhadap Loyalitas Konsumen Melalui Kepuasan Konsumen di PO. Nugroho." Jurnal of Marketing, Semarang: Universitas Dian Nuswantoro Semarang.

Yesi Agustin Stantia. (2018) "Pengaruh Kualitas Pelayanan, Kualitas Produk Dan Emotional Factor Terhadap Kepuasan Konsumen Batik Gajah Mada.” Skripsi (tidak dipublikasi), Tulungagung: Institut Agama Islam Negeri Tulungagung.

Yineu Nur Layaalin. (2017). "Pengaruh Kualitas Pelayanan, Harga dan Fasilitas Terhadap Kepuasan Pelanggan Pada Top 40 Family Karaoke Yogyakarta.” Skripsi (tidak dipublikasi), Yogyakarta: Universitas Negeri Yogyakarta.

Yusuf Helmi Aziz. (2019). "Analisis Pengaruh Kualitas Produk dan Harga Terhadap Keputusan Pembelian Melalui Word of Mouth (WOM) Sebagai Variabel Intervening Pada Es Coklat Ndeso di Taman Paseban Bantul." Skripsi (tidak dipublikasi), Yogyakarta: STIE Widya Wiwaha.

http://mastaritanova.blogspot.com/2012/09/penelitian-kuantitatif.html

diakses pada 14 Desember 2019, 22:26

https://pengertianahli.id/2013/11/pengertian-data-dan-jenis-data.html

diakses pada 14 Desember 2019, 22:37

https://thingdiputra.github.io/

diakses pada 30 Desember 2019 23:22 